\title{
Pengaruh Leverage dan Profitabilitas terhadap Harga Saham pada Perusahaan Sub Sektor Konstruksi dan Bangunan yang Terdaftar di Bursa Efek Indonesia Periode 2017-2019
}

\author{
Dinda Nadia $^{1 *}$, Gede Putu Agus Jana Susila ${ }^{2}$ iD \\ ${ }^{1232}$ Program Studi Manajemen, Jurusan Manajemen, Fakultas Ekonomi, Universitas Pendidikan Ganesha \\ *dindanadia04@undiksha.ac.id*
}

\section{Abstrak}

Penelitian ini bertujuan untuk menguji dan mengetahui pengaruh leverage dan profitabilitas terhadap harga saham secara simultan dan parsial. Rancangan penelitian ini adalah penelitian kuantitatif kausal. Subjek penelitian ini adalah perusahaan Sub Sektor Konstruksi dan Bangunan yang terdaftar di Bursa Efek Indonesia dan objek penelitian ini adalah leverage, profitabilitas, dan harga saham. Teknik pengambilan sampel yaitu purposive sampling dengan jumlah 15 perusahaan. Data dikumpulkan dengan pencatatan dokumen, kemudian dianalisis menggunakan analisis regresi linear berganda. Hasil penelitian menunjukkan bahwa (1) leverage dan profitabilitas secara simultan berpengaruh signifikan terhadap harga saham sebesar $52,2 \%$, (2) leverage secara parsial berpengaruh positif dan signifikan terhadap harga saham sebesar $51,4 \%$, $(3)$ profitabilitas secara parsial berpengaruh positif dan tidak signifikan terhadap harga saham sebesar 1,5\%.

Kata Kunci: Leverage, Profitabilitas, dan Harga Saham

\section{Abstract}

This study aims to examine and determine the effect of leverage and profitability on stock prices simultaneously and partially. The design of this research was causal quantitative research. The subject of this research is the construction and building sub-sector companies listed on the Indonesia Stock Exchange and the objects of this research were leverage, profitability, and stock prices. The sampling technique was purposive sampling with a total of 15 companies. Data were collected by recording documents, then analyzed using multiple linear regression analysis. The results showed that (1) leverage and profitability simultaneously had a significant effect on stock prices of $52.2 \%$, (2) leverage partially had a positive and significant effect on stock prices of 51.4\%, (3) partially profitability had a positive effect and not significant to the stock price of $1.5 \%$.

Keywords: Leverage, Profitability, And Stock Prices

\section{Pendahuluan}

Seiring dengan perkembangan perekonomian yang saat ini mengalami pertumbuhan yang cukup pesat, kini investasi merupakan salah satu alternatif yang dilakukan oleh seseorang untuk mendapatkan keuntungan di masa depan. Salah satu sarana investasi yaitu pasar modal yang mempertemukan investor yang memiliki kelebihan dana dengan harapan mendapatkan keuntungan dan perusahaan yang membutuhkan modal demi pengembangan kemajuan usahanya. Salah satu instrumen pasar modal yang memiliki tingkat risiko yang tinggi, tapi memiliki tingkat pengembalian yang tinggi yaitu saham. Saham adalah tanda bukti penyertaan kepemilikan modal atau dana pada suatu perusahaan.

Investor yang memiliki saham dianggap sebagai bagian dari pemilik perusahaan yang mempunyai hak untuk menentukan jalannya perusahaan. Manfaat lainnya dari kepemilikan saham adalah manfaat finansial berupa perolehan dividen dan capital gain. Investor pasti mengharapkan manfaat finansial yang maksimal dari investasi sahamnya. Karenanya sebelum investor mengambil keputusan berinvestasi di Bursa Efek Indonesia (BEI), investor

$\begin{array}{ll}\text { History: } & \text { Publisher: Undiksha Press } \\ \text { Received: August } 2021 & \text { Licensed: This work is licensed under } \\ \text { Revised: Oktober } 2021 & \text { a Creative Commons Attribution 3.0 License } \\ \text { Accepted: November } 2021 & \end{array}$


harus mengetahui dan mempertimbangkan sejumlah informasi untuk memilih saham perusahaan yang memiliki prospek baik ke depannya. Untuk melihat prospek suatu perusahaan, investor dapat menilai dari harga sahamnya. Bagi investor harga saham yang terus meningkat mencerminkan prospek perusahaan yang baik dan menguntungkan di masa depan.

Perusahaan konstruksi dan bangunan merupakan salah satu sub sektor industri yang terdaftar di BEI. Sub sektor konstruksi dan bangunan adalah salah satu sektor andalan untuk mendorong pertumbuhan ekonomi. Menurut studi yang dilakukan Biro Pusat Statistik (BPS) menunjukkan bahwa sektor konstruksi berada di posisi ketiga sebagai sumber utama pertumbuhan ekonomi Indonesia. Sektor konstruksi yang berkembang menjadikan perekonomian Indonesia pada tahun 2017 tumbuh sebesar 5.01\% dan PDB sebesar 10.38\%, lebih tinggi dari tahun sebelumnya. Perkembangan industri konstruksi dan bangunan begitu pesat, terbukti dengan semakin banyaknya jumlah perusahaan yang terdaftar di BEI. Pada tahun 1990-an jumlah perusahaan yang terdaftar hanya sebanyak satu perusahaan saja, namun memasuki tahun 2000-an hingga tahun 2019 jumlah perusahaan terdaftar menjadi sebanyak 17 perusahaan.

Berdasarkan analisis laporan keuangan, maka diperoleh rata-rata nilai harga saham pada perusahaan sektor property, real estate dan konstruksi bangunan yang terdaftar di BEI periode 2017-2019 yang dapat dilihat pada Tabel 1.

Tabel 1. Rata-rata Harga Saham Pada Perusahaan Sektor Property, Real Estate dan Konstruksi Bangunan Periode 2017-2019

\begin{tabular}{crrrrr}
\hline \multirow{2}{*}{ No. } & \multirow{2}{*}{ Nama Sub Sektor } & \multicolumn{2}{c}{ Rata-rata Nilai Harga Saham } & \multirow{2}{*}{ Keterangan } \\
\cline { 3 - 5 } & & $\mathbf{2 0 1 7}$ & $\mathbf{2 0 1 8}$ & $\mathbf{2 0 1 9}$ & \\
\hline 1. & Property dan Real Estate & $\mathrm{Rp} \mathrm{1.702,-}$ & $\mathrm{Rp} \mathrm{1.523,-}$ & $\mathrm{Rp} \mathrm{1.461,-}$ & Menurun \\
\hline 2. & Konstruksi dan Bangunan & $\mathrm{Rp} \mathrm{1.267,-}$ & $\mathrm{Rp} \mathrm{1.091,-}$ & $\mathrm{Rp} \mathrm{986,-}$ & Menurun \\
\hline
\end{tabular}

Sumber: Laporan Keuangan di BEI (data diolah)

Berdasarkan data Tabel 1 dapat diketahui bahwa kedua sub sektor yaitu sub sektor property dan real estate maupun sub sektor konstruksi dan bangunan mengalami penurunan nilai pertumbuhan harga saham, namun sub sektor konstruksi dan bangunan yang menunjukkan penurunan nilai pertumbuhan harga saham yang cukup besar yaitu pada tahun 2018 mengalami penurunan sebesar $-13,89 \%$ dan pada tahun 2019 kembali mengalami penurunan sebesar $-9,62 \%$. Jadi dapat disimpulkan penurunan harga saham tersebut diduga dipengaruhi oleh leverage dan profitabilitas. Hal ini sejalan dengan teori yang dikemukakan oleh Darmadji dan Fakhruddin (2011:16) bahwa, salah satu cara untuk mengetahui terjadinya penurunan harga saham yaitu dengan melakukan analisis fundamental seperti analisis kinerja keuangan perusahaan yang terdiri dari rasio likuiditas, leverage, aktivitas, dan profitabilitas. Sehingga dapat dikatakan bahwa leverage dan profitabilitas dapat mempengaruhi penurunan harga saham. Hal ini sejalan dengan hasil penelitian yang dilakukan oleh Ariyanti, dkk (2016) yang menyatakan bahwa leverage dan profitabilitas berpengaruh signifikan terhadap harga saham.

Salah satu tujuan perusahaan yaitu memiliki nilai perusahaan yang tinggi, dengan tingginya nilai perusahaan maka akan dapat memberikan kemakmuran bagi pemegang sahamnya. Harga saham juga menunjukkan nilai suatu perusahaan. Sehingga seringkali dikatakan memaksimumkan nilai perusahaan juga berarti memaksimumkan kekayaan pemegang saham. Dengan semakin tinggi harga saham, maka semakin tinggi pula nilai 
perusahaan tersebut dan sebaliknya. Jadi semakin tinggi harga saham sebuah perusahaan maka akan semakin tinggi pula kemakmuran para pemegang sahamnya. Namun, harga saham di pasar modal selalu mengalami pergerakan baik itu naik maupun turun. Pergerakan saham pada umumnya dipengaruhi beberapa faktor yaitu faktor eksternal dan internal. Faktor eksternal atau teknikal yaitu untuk mempelajari tentang perilaku pasar yang diterjemahkan ke dalam grafik riwayat harga dengan tujuan untuk memprediksi harga di masa yang akan datang. Sedangkan faktor internal atau faktor fundamental adalah studi tentang ekonomi, industri dan kondisi perusahaan untuk memperhitungkan nilai dari saham perusahaan yang sering dikaitkan dengan analisis kinerja keuangan perusahaan. Analisis rasio keuangan dapat digunakan untuk menilai kinerja keuangan suatu perusahaan, rasio keuangan seperti rasio likuiditas, rasio solvabilitas (leverage), maupun rasio profitabilitas.

Leverage merupakan rasio yang menunjukkan seberapa besar perusahaan tersebut dibiayai oleh utang. Syamsudin (2007) menyatakan bahwa rasio leverage merupakan kemampuan perusahaan untuk memenuhi kewajiban keuangannya apabila perusahaan tersebut dilikuidasikan baik kewajiban jangka pendek maupun kewajiban jangka panjang. Pihak perusahaan harus selalu mempertimbangkan penggunaan utang di dalam perusahaan dengan cara membandingkannya dengan pencapaian tingkat laba yang lebih tinggi. Tingkat utang perusahaan harus dijaga karena apabila tingkat utang perusahaan terlalu tinggi akan menyebabkan investor takut untuk berinvestasi.

Profitabilitas dapat diartikan sebagai kemampuan suatu perusahaan untuk memperoleh laba atau keuntungan dari semua kegiatan dan sumber daya yang dimilikinya. Laba dianggap sebagai faktor utama yang dapat mengukur tingkat pencapaian perusahaan dengan mengelola berbagai dana dan sumber daya yang dimiliki oleh perusahaan melalui seluruh aktivitas yang dilakukan perusahaan. Menurut Kasmir (2015:196) rasio profitabilitas merupakan rasio untuk menilai kemampuan perusahaan dalam mencari keuntungan. Profitabilitas menyangkut efisiensi perusahaan yang menggunakan modal, baik modal sendiri maupun modal asing. Tingginya profitabilitas merupakan salah satu sinyal positif bagi investor untuk membeli saham pada perusahaan tersebut sehingga akan menyebabkan permintaan saham meningkat dan mendorong kenaikan harga saham.

Berdasarkan laporan keuangan pada perusahaan sub sektor konstruksi dan bangunan periode 2017-2019 dapat disimpulkan bahwa beberapa perusahaan mengalami penurunan nilai leverage namun tidak diikuti dengan peningkatan harga saham, begitu pula sebaliknya. hal ini tidak sejalan dengan teori yang dikemukakan oleh Fahmi (2012:62) bahwa harga saham dipengaruhi oleh leverage yang merupakan gambaran dari kemampuan perusahaan dalam memenuhi kewajibannya untuk membayar utang. Semakin tinggi leverage akan menyebabkan harga saham menurun, begitu juga sebaliknya. Selain itu juga terdapat beberapa perusahaan yang mengalami penurunan profitabilitas namun tidak diikuti dengan penurunan harga saham, begitu pula sebaliknya. Hal ini tidak sejalan dengan teori yang dikemukakan oleh Husnan (2001:317) yaitu apabila kemampuan perusahaan dalam menghasilkan laba meningkat, maka harga saham juga akan meningkat. Nilai profitabilitas yang tinggi akan memberikan dampak positif dan dapat memberikan kemakmuran bagi investor sehingga hal tersebut dapat mengakibatkan naiknya harga saham suatu perusahaan, begitu pula sebaliknya.

Adapun tujuan penelitian ini yaitu untuk menguji dan menganalisis pengaruh: (1) pengaruh leverage dan profitabilitas terhadap harga saham pada perusahaan Sub Sektor Konstruksi dan Bangunan yang terdaftar di BEI periode 2017-2019, (2) pengaruh leverage terhadap harga saham pada perusahaan Sub Sektor Konstruksi dan Bangunan yang terdaftar di BEI periode 2017-2019, (3) pengaruh profitabilitas terhadap harga saham pada perusahaan Sub Sektor Konstruksi dan Bangunan yang terdaftar di BEI periode 2017-2019. 
Jogiyanto (2015:8) mendefinisikan harga saham adalah harga yang terjadi di pasar bursa pada saat tertentu yang akan ditentukan oleh pelaku pasar dan ditentukan oleh permintaan dan penawaran saham yang bersangkutan di pasar modal. Menurut Tandelilin (2010) harga saham merupakan harga yang terjadi di pasar saham, yang akan sangat berarti bagi perusahaan karena harga tersebut menentukan besarnya nilai perusahaan. Semakin tinggi harga saham maka semakin tinggi pula nilai perusahaan, nilai perusahaan yang tinggi menjadi keinginan para pemilik perusahaan sebab dengan nilai perusahaan yang tinggi menunjukan kemakmuran pemegang saham juga tinggi. Jadi dapat disimpulkan bahwa semakin tinggi harga saham menyebabkan semakin tinggi pula nilai perusahaan yang berdampak pada ketertarikan investor untuk menanamkan sahamnya, begitu pula sebaliknya. Dalam penelitian ini yang digunakkan untuk pengukuran harga saham adalah harga penutupan (close price).

Leverage

Menurut Kasmir (2015:151) rasio leverage merupakan rasio yang digunakan untuk mengukur sejauh mana aktiva perusahaan dibiayai dengan utang. Rasio leverage merupakan kemampuan perusahaan untuk memenuhi kewajiban keuangannya apabila perusahaan tersebut dilikuidasikan baik kewajiban jangka pendek maupun kewajiban jangka panjang (Syamsudin, 2007). Kodrat dan Kurniawan (2010:234) menyatakan bahwa rasio leverage merupakan besarnya aset perusahaan yang didanai oleh pendanaan dari pihak luar atau utang perusahaan. Dari beberapa pendapat ahli dapat disimpulkan bahwa rasio leverage merupakan rasio untuk mengukur sejauh mana aktiva perusahaan didanai oleh pendanaan dari pihak luar atau utang perusahaan. Dalam penelitian ini yang digunakkan untuk pengukuran leverage adalah Debt to Asset Ratio (DAR).

\section{Profitabilitas}

Fahmi (2013:135) mendefinisikan rasio profitabilitas adalah rasio yang mengukur efektivitas manajemen secara keseluruhan yang ditunjukkan oleh besar kecilnya tingkat keuntungan yang diperoleh dalam hubungannya dengan penjualan maupun investasi. Profitabilitas yaitu kemampuan suatu perusahaan yang menghasilkan keuntungan (profit) pada tingkat penjualan aset dan modal saham tertentu (Husnan, 2001). Menurut Kasmir (2015:196) rasio profitabilitas merupakan rasio untuk menilai kemampuan perusahaan dalam mencari keuntungan. Dari beberapa pendapat ahli dapat disimpulkan bahwa rasio profitabilitas adalah rasio yang digunakan untuk mengukur kemampuan suatu perusahaan dalam memperoleh keuntungan. Dalam penelitian ini yang digunakan untuk pengukuran profitabilitas adalah Return On Asset (ROA).

\section{Hubungan Leverage dan Profitabilitas terhadap Harga Saham}

Brigham dan Houston (2010:150) menyatakan bahwa jika rasio manajemen aset, likuiditas, leverage, dan profitabilitas terlihat baik dan berjalan secara stabil maka akan menyebabkan rasio nilai pasar meninggi, harga saham tinggi, dan pihak manajemen perusahaan telah bekerja dengan efisien. Dengan kata lain leverage dan profitabilitas secara bersama-sama mempengaruhi harga saham. Hal tersebut sejalan dengan hasil penelitian yang dilakukan Ariyanti, dkk (2016) yang menyatakan bahwa leverage dan profitabilitas secara simultan berpengaruh terhadap harga saham.

$H_{1}$ : Ada pengaruh leverage dan profitabilitas terhadap harga saham 
Hubungan Leverage terhadap Harga Saham

Fahmi (2012:62) menyatakan bahwa naik turunnya harga saham dapat dipengaruhi oleh rasio leverage yang merupakan gambaran mengenai kemampuan perusahaan dalam memenuhi kewajibannya dengan membayar utang secara konsisten. Tingginya leverage suatu perusahaan, membuat investor ragu untuk berinvestasi, karena sebagian pendapatan dari perusahaan akan digunakan untuk membayar utang sehingga keuntungan yang diperoleh investor akan berkurang. Hal tersebut sejalan dengan penelitian yang dilakukan Agustami (2019) yang menyatakan bahwa leverage berpengaruh negatif terhadap harga saham.

$\mathrm{H}_{2}$ : Ada pengaruh leverage terhadap harga saham

\section{Hubungan Profitabilitas terhadap Harga Saham}

Husnan (2001: 317) menyatakan bahwa apabila kemampuan perusahaan dalam menghasilkan laba meningkat, maka harga saham juga akan meningkat, hal ini menunjukkan jika profitabilitas meningkat maka nilai perusahaan juga meningkat. Dengan kata lain meningkatnya profitabilitas suatu perusahaan menyebabkan harga saham perusahaan tersebut juga meningkat, begitu pula sebaliknya. Hal tersebut sejalan dengan penelitian yang dilakukan Dewi (2015) dan Zaki, dkk (2017) yang menyatakan bahwa profitabilitas berpengaruh positif dan signifikan terhadap harga saham.

$H_{3}$ : Ada pengaruh profitabilitas terhadap harga saham

\section{Metode}

Rancangan penelitian yang digunakan pada penelitian ini adalah penelitian kuantitatif kausal. Penelitian kuantitatif kausal merupakan penelitian yang bertujuan untuk menganalisis hubungan sebab-akibat antara variabel independen dengan variabel dependen (Sugiyono, 2007). Variabel yang digunakan dalam penelitian ini adalah dua variabel independen yaitu leverage $\left(\mathrm{X}_{1}\right)$ dan profitabilitas $\left(\mathrm{X}_{2}\right)$, serta satu variabel dependen yaitu harga saham $(\mathrm{Y})$.

Subjek dari penelitian ini adalah perusahaan Sub Sektor Konstruksi dan Bangunan yang terdaftar di BEI. Sedangkan objek penelitian ini adalah leverage $\left(\mathrm{X}_{1}\right)$, profitabilitas $\left(\mathrm{X}_{2}\right)$, dan harga saham (Y).

Pemilihan sampel dalam penelitian ini menggunakan metode purposive sampling dengan kriteria: (1) perusahaan Sub Sektor Konstruksi dan Bangunan yang terdaftar di BEI periode 2017-2019, (2) perusahaan Sub Sektor Konstruksi dan Bangunan yang mempublikasikan laporan keuangan dan laporan tahunan lengkap di BEI periode 2017-2019. Berdasarkan kriteria di atas, jumlah sampel yang digunakan dalam penelitian ini adalah 15 perusahaan.

Metode pengumpulan data yang digunakan adalah pencatatan dokumen. Sumber data penelitian ini yaitu laporan keuangan tahunan yang terdiri dari neraca, laporan arus kas, dan laporan laba/rugi yang diakses melalui situs internet www.idx.co.id. Teknik analisis yang digunakan yaitu teknik analisis regresi linear berganda. Pengolahan data dilakukan dengan menggunakan program SPSS versi 23.0 for Windows. Sebelum melakukan analisis regresi linear berganda, terlebih dahulu dilakukan uji asumsi klasik yang terdiri dari uji normalitas, uji multikolinearitas, uji heteroskedastisitas dan uji autokorelasi.

\section{Hasil dan Pembahasan}

Berdasarkan hasil uji model analisis regresi linear berganda dengan bantuan program aplikasi komputer SPSS versi 23.0 for Windows diperoleh asil pengujian berupa ringkasan hasil output SPSS seperti pada Tabel 2.

Tabel 2. Ringkasan Hasil Output SPSS Tentang Pengaruh Leverage $\left(\mathrm{X}_{1}\right)$ dan Profitabilitas $\left(\mathrm{X}_{2}\right)$ Terhadap Harga Saham (Y) 


\begin{tabular}{|c|c|c|c|c|c|}
\hline Parameter & Nilai & p-value & Alpha $(\alpha)$ & Keputusan & Simpulan \\
\hline $\operatorname{Ryx}_{1} x_{2}$ & 0,723 & 0,000 & 0,05 & Menerima $\mathrm{H}_{\mathrm{a}}$ & $\begin{array}{l}\text { Adanya pengaruh simultan dari leverage } \\
\left(\mathrm{X}_{1}\right) \text { dan profitabilitas }\left(\mathrm{X}_{2}\right) \text { terhadap } \\
\text { harga saham }(\mathrm{Y}) \text {. }\end{array}$ \\
\hline $\mathrm{R}^{2} \mathrm{yx}_{1} \mathrm{x}_{2}$ & 0,522 & - & - & - & $\begin{array}{l}\text { Besar sumbangan pengaruh simultan } \\
\text { dari leverage }\left(\mathrm{X}_{1}\right) \text { dan profitabilitas }\left(\mathrm{X}_{2}\right) \\
\text { terhadap harga saham }(\mathrm{Y}) \text { yaitu } 52,2 \% \text {. }\end{array}$ \\
\hline $\mathrm{Pyx}_{1}$ & 0,717 & 0,000 & 0,05 & Menerima $\mathrm{H}_{\mathrm{a}}$ & $\begin{array}{l}\text { Adanya pengaruh positif dan signifikan } \\
\text { secara parsial dari leverage }\left(\mathrm{X}_{1}\right) \\
\text { terhadap harga saham }(\mathrm{Y}) \text {. }\end{array}$ \\
\hline $\mathrm{P}^{2} \mathrm{yx}_{1}$ & 0,514 & - & - & - & $\begin{array}{l}\text { Besar sumbangan pengaruh secara } \\
\text { parsial dari leverage }\left(\mathrm{X}_{1}\right) \text { terhadap } \\
\text { harga saham }(\mathrm{Y}) \text { yaitu } 51,4 \% \text {. }\end{array}$ \\
\hline $\mathrm{Pyx}_{2}$ & 0,123 & 0,426 & 0,05 & Menolak $\mathrm{H}_{\mathrm{a}}$ & $\begin{array}{l}\text { Adanya pengaruh positif namun tidak } \\
\text { signifikan secara parsial dari } \\
\text { profitabilitas }\left(\mathrm{X}_{2}\right) \text { terhadap harga saham } \\
(\mathrm{Y}) \text {. }\end{array}$ \\
\hline $\mathrm{P}^{2} \mathrm{yx}_{2}$ & 0,015 & - & - & - & $\begin{array}{l}\text { Besar sumbangan pengaruh secara } \\
\text { parsial dari profitabilitas }\left(\mathrm{X}_{2}\right) \text { terhadap } \\
\text { harga saham }(\mathrm{Y}) \text { yaitu } 1,5 \% \text {. }\end{array}$ \\
\hline$\varepsilon$ & 0,478 & - & - & - & $\begin{array}{l}\text { Besar sumbangan pengaruh variabel lain } \\
\text { (c) terhadap harga saham (Y) yaitu } \\
47,8 \% \text {. }\end{array}$ \\
\hline$\alpha$ & $\begin{array}{c}- \\
695,263 \\
\end{array}$ & 0,018 & 0,05 & Signifikan & Bisa memprediksi harga saham. \\
\hline$\beta_{1}$ & 30,114 & 0,000 & 0,05 & Signifikan & Bisa memprediksi harga saham. \\
\hline$\beta_{2}$ & 7,224 & 0,426 & 0,05 & $\begin{array}{c}\text { Tidak } \\
\text { Signifikan }\end{array}$ & Tidak bisa memprediksi harga saham. \\
\hline
\end{tabular}

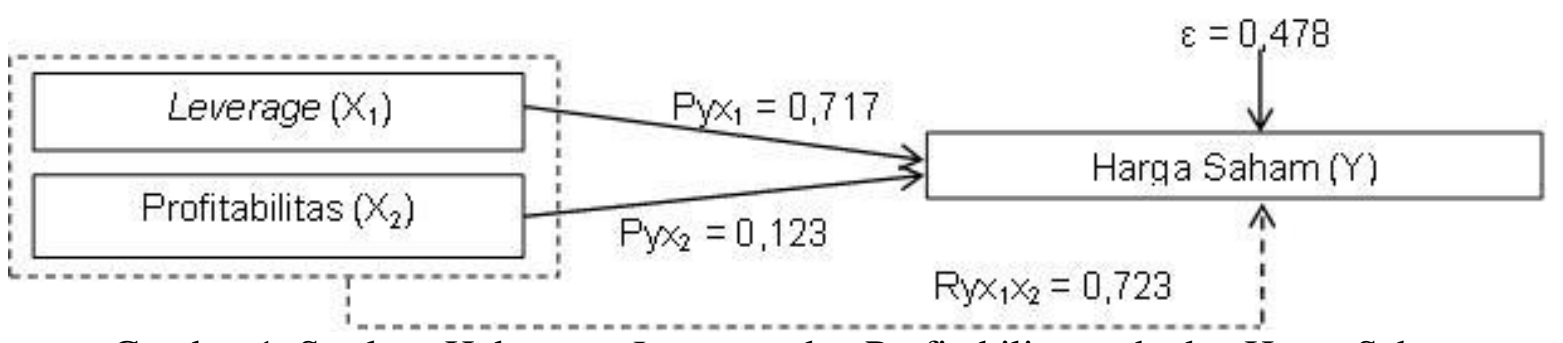

Gambar 1. Struktur Hubungan Leverage dan Profitabilitas terhadap Harga Saham

Berdasarkan hasil uji regresi linear berganda menunjukkan nilai Ryx $1 \times 2=0,723$ dengan p-value $0,000<\alpha 0,05$, sehingga Ha diterima yang artinya ada pengaruh simultan leverage (X1) dan profitabilitas (X2) terhadap harga saham (Y). Adapun besarnya sumbangan pengaruh simultan leverage (X1) dan profitabilitas (X2) terhadap harga saham (Y) adalah sebesar 52,2\%, sedangkan sisanya sebesar $47,8 \%$ dipengaruhi oleh variabel lain yang tidak diteliti.

Berdasarkan hasil uji regresi linear berganda menunjukkan nilai Pyx $1=0,717$ dengan $\mathrm{p}$ value $0,000<\alpha 0,05$, sehingga Ha diterima yang artinya ada pengaruh positif dan signifikan leverage (X1) terhadap harga saham (Y). Adapun besarnya sumbangan pengaruh leverage (X1) terhadap harga saham (Y) adalah sebesar 51,4\%. Sedangkan nilai Pyx2=0,123 dengan p-value $0,426>\alpha 0,05$, sehingga Ha ditolak yang artinya ada pengaruh tidak signifikan 
profitabilitas (X2) terhadap harga saham (Y). Adapun besarnya sumbangan pengaruh profitabilitas (X2) terhadap harga saham (Y) adalah sebesar 1,5\%.

Berdasarkan hasil uji regresi linear berganda pada Tabel 2 diperolehan nilai konstanta $(\alpha)$ sebesar $-695,263$. Nilai koefisien regresi leverage $(\beta 1)$ sebesar 30,114 dan nilai koefisien regresi profitabilitas $(\beta 2)$ sebesar 7,224. Sehingga, persamaan regresi diformulasikan sebagai berikut.

$$
\hat{\mathrm{Y}}=-695,263+30,114 \mathrm{X} 1+7,224 \mathrm{X} 2
$$

Interpretasi hasil regresi linier berganda sebagai berikut.

1. Konstanta $(\alpha)$ sebesar -695,263 artinya bahwa apabila leverage (X1) dan profitabilitas (X2) nilainya sama dengan nol, maka harga saham (Y) sebesar -695,263.

2. Nilai koefisien leverage ( $\beta 1$ ) sebesar 30,114 berpengaruh positif terhadap harga saham (Y). Hal ini mengandung arti bahwa setiap kenaikan leverage (X1) satu satuan maka variabel harga saham (Y) mengalami kenaikan sebesar 30,114 sehingga menjadi 665,149 dengan asumsi bahwa variabel independen yang lainnya tetap.

3. Nilai koefisien profitabilitas $(\beta 2)$ sebesar 7,224 berpengaruh positif terhadap harga saham (Y). Hal ini mengandung arti bahwa setiap kenaikan profitabilitas (X2) satu satuan maka variabel harga saham (Y) mengalami kenaikan sebesar 7,224 sehingga menjadi -688,039 dengan asumsi bahwa variabel independen yang lainnya tetap.

4. Nilai error $(\varepsilon)$ sebesar 0,478 dengan asumsi bahwa masih ada variabel lain yang mempengaruhi harga saham selain leverage dan profitabilitas.

Berdasarkan hasil penelitian yang telah dilakukan menunjukkan bahwa secara simultan variabel leverage $\left(\mathrm{X}_{1}\right)$ dan profitabilitas $\left(\mathrm{X}_{2}\right)$ berpengaruh signifikan terhadap harga saham (Y) dengan besarnya pengaruh sebesar 52,2\% pada Perusahaan Sub Sektor Konstruksi dan Bangunan yang terdaftar di BEI Periode 2017-2019. Pernyataan tersebut juga diperkuat oleh hasil penelitian Ariyanti, dkk (2016) yang menyatakan bahwa profitabilitas dan leverage secara simultan berpengaruh signifikan terhadap harga saham. Hasil penelitian tersebut sejalan dengan pernyataan Brigham dan Houston (2010:150) bahwa jika rasio manajemen aset, likuiditas, leverage, dan profitabilitas terlihat baik dan berjalan secara stabil maka akan menyebabkan rasio nilai pasar meninggi, harga saham tinggi, dan pihak manajemen perusahaan telah bekerja dengan efisien.

Berdasarkan hasil penelitian yang telah dilakukan menunjukkan bahwa variabel leverage (X1) berpengaruh positif dan signifikan terhadap harga saham (Y) dengan besarnya pengaruh sebesar 51,4\% pada Perusahaan Sub Sektor Konstruksi dan Bangunan yang terdaftar di BEI Periode 2017-2019. Hasil penelitian ini didukung oleh penelitian yang dilakukan oleh Tantri (2019) yang menyatakan leverage berpengaruh positif dan signifikan terhadap harga saham. Hasil tersebut menunjukkan bahwa semakin besar leverage maka akan semakin tinggi harga saham perusahaan, begitu pula sebaliknya.

Berdasarkan hasil penelitian yang telah dilakukan menunjukkan bahwa variabel profitabilitas (X2) berpengaruh positif namun tidak signifikan terhadap harga saham (Y) dengan besarnya pengaruh sebesar 1,5\% pada Perusahaan Sub Sektor Konstruksi dan Bangunan yang terdaftar di BEI Periode 2017-2019. Hasil tersebut didukung oleh penelitian yang dilakukan oleh Wulandari (2019) yang menyatakan bahwa profitabilitas berpengaruh tidak signifikan terhadap harga saham. Hasil penelitian ini sejalan dengan pernyataan Husnan (2001:317) bahwa apabila kemampuan perusahaan dalam menghasilkan laba meningkat, maka harga saham juga akan meningkat, hal ini menunjukkan jika profitabilitas meningkat maka nilai perusahaan juga meningkat.

\section{Simpulan dan Saran}

Berdasarkan hasil penelitian dan pembahasan yang telah dipaparkan, maka diperoleh simpulan sebagai berikut: (1) Ada pengaruh leverage dan profitabilitas secara simultan 
terhadap harga saham pada perusahaan Sub Sektor Konstruksi dan Bangunan yang terdaftar di BEI periode 2017-2019, (2) Ada pengaruh positif dan signifikan leverage terhadap harga saham pada perusahaan Sub Sektor Konstruksi dan Bangunan yang terdaftar di BEI periode 2017-2019, (3) Ada pengaruh positif dan tidak signifikan profitabilitas terhadap harga saham pada perusahaan Sub Sektor Konstruksi dan Bangunan yang terdaftar di BEI periode 20172019.

Berdasarkan hasil pembahasan dan simpulan yang telah dikemukakan sebelumnya, maka dapat diajukan beberapa saran sebagai berikut: (1) Bagi penelitian berikutnya diharapkan menggunakan rasio keuangan lainnya dan menambahkan variabel lain yang tidak diteliti pada penelitian ini seperti ukuran perusahaan, pertumbuhan aset, kinerja keuangan, dan lain-lain, (2) Bagi perusahaan diharapkan dapat menjaga kinerja perusahaan sehingga dapat meningkatkan harga sahamnya di Bursa Efek Indonesia, selain itu juga diharapkan tingkat leverage tidak terlalu tinggi agar hutang perusahaan tidak banyak sehingga lebih menarik investor untuk berinvestasi, (3) Bagi investor diharapkan lebih memperhatikan analisis yang digunakan baik itu teknikal maupaun fundamental, selain itu faktor-faktor yang mempengaruhi harga saham baik itu faktor internal maupun faktor eksternal, khususnya laporan keuangan yang mencerminkan kondisi keuangan dan kinerja suatu perusahaan.

\section{Daftar Pustaka}

Agustami, Silviana dan Pitriani Syahida. 2019. "Pengaruh Nilai Pasar, Profitabilitas, dan Leverage terhadap Harga Saham (Studi pada Perusahaan Sektor Industri Barang Konsumsi yang Terdaftar di Bursa Efek Indonesia (BEI) Periode 2013-2017)". Organum: Jurnal Saintifik Manajemen dan Akuntansi Vol. 2 No.2.

Ariyanti, Sari, dkk. 2016. "Pengaruh Profitabilitas dan Leverage terhadap Harga Saham (Studi pada Perusahaan Konstruksi dan Bangunan yang Terdaftar di Bursa Efek Indonesia Periode 2011-2014)". Jurnal Administrasi Bisnis (JAB) Vol. 35 No.2.

Brigham, Eugene F dan Joel F. Houston. 2010. Dasar-dasar Manajemen Keuangan. Edisi Sebelas. Jakarta: Salemba Empat.

Bursa Efek Indonesia. 2017. Laporan Keuangan dan Tahunan. Terdapat di www.idx.co.id (diakses tanggal 17 Oktober 2020).

Bursa Efek Indonesia. 2018. Laporan Keuangan dan Tahunan. Terdapat di www.idx.co.id (diakses tanggal 17 Oktober 2020).

Bursa Efek Indonesia. 2019. Laporan Keuangan dan Tahunan. Terdapat di www.idx.co.id (diakses tanggal 17 Oktober 2020).

Darmadji, Tjiptono dan Fakhruddin, H. M. 2011. Pasar Modal di Indonesia. Jakarta Salemba Empat.

Dewi, Linda Kania. 2015. "Pengaruh Profitabilitas, Leverage dan Likuiditas Terhadap Harga Saham pada Perusahaan Industri Makanan dan Minuman di Bursa Efek Indonesia”. eJurnal Katalogis Vol.3 No.8.

Fahmi, I. 2013. Pengantar Manajemen Keuangan. Bandung: Alfabeta.

Fahmi, Irham. 2012. Pengantar Pasar Modal. Bandung: Alfabeta

Husnan, Suad. 2001. Dasar-Dasar Teori Portofolio Dan Analisis Sekuritas. Yogyakarta: AMP YPKN. 
Jogiyanto, H. 2013. Teori Portofolio dan Analisis Investasi. Edisi Kedelapan. Yogyakarta: BPFE.

Kasmir. 2015. Analisis Laporan Keuangan. Edisi Kedelapan. Jakarta: PT Raja grafindo Persada.

Kodrat, David Sukardi dan Kurniawan Indonanjaya. 2010. Manajemen Investasi: Pendekatan Teknikal dan Fundamental untuk Analisis Harga Saham. Yogyakarta: Graha Ilmu.

Munawir, S. 2007. Analisa Laporan Keuangan. Edisi Keempat. Yogyakarta: Liberty.

Sugiyono. 2007. Metode Penelitian Kuantitatif Kualitatif dan R\&D. Bandung: Alfabeta.

Syamsudin, Lukman. 2007. Manajemen Keuangan Perusahaan. Jakarta: PT Raja grafindo Persada.

Tandelilin, E. 2010. Pasar Modal Manajemen Portofolio dan Investasi. Yogyakarta: PT Kanisius.

Tantri, Erdina Novia dan Djawoto. 2019. "Pengaruh Profitabilitas, Leverage dan Likuiditas terhadap Harga Saham pada Perusahaan Manufaktur Sub Sektor Food and Beverage yang terdaftar di Bursa Efek Indonesia”. Jurnal Ilmu dan Riset Manajemen Vo.8 No.10.

Wulandari, Ade Indah dan Ida Bagus Badjra. 2019. "Pengaruh Profitabilitas terhadap Harga Saham pada Perusahaan LQ-45 di Bursa Efek Indonesia (BEI)". E-Jurnal Manajemen Vol.8 No.9.

Zaki, Muhammad, dkk. 2017. "Pengaruh Profitabilitas, Leverage Keuangan dan Ukuran Perusahaan terhadap Harga Saham (Studi Pada Perusahaan Manufaktur Yang Terdaftar di Bursa Efek Indonesia Periode 2005-2014)”. Jurnal Megister Akuntansi Vol.6 No.2. 